Asia Proceedings of Social Sciences

(APSS)

www.readersinsight.net/APSS

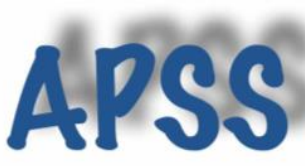

\title{
FINTECH AND THE CHALLENGE OF DIGITAL DISRUPTION IN TAKAFUL OPERATION
}

Azwina Wati Abdull Manaf*

Lecturer Faculty of Law, Multimedia University

Malaysia

\section{Norazuan binti Amiruddin}

Lecturer Faculty of Law, Multimedia University

Malaysia

*Corrosponding author's Email: $\underline{\text { azwina.manaf@mmu.edu.my }}$

Author's Biography

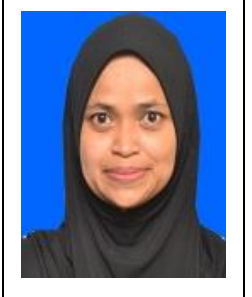

The author was called to the Bar in December 2005 and practice law as a Legal Assistant with Messrs. Mohamed Ridza \& Co, Kuala Lumpur and later in several firms. She had experience in corporate, conveyancing as well as civil litigation matters before joined Multimedia University in 2012. She actively involved in publication especially in field of Islamic Banking and Finance. Currently she is a Chair for Centre of Shariah Law of the Faculty of Law, Multimedia University, Melaka.

Peer-review under responsibility of $3^{\text {rd }}$ Asia International Multidisciplanry Conference 2019 editorial board (http://www.utm.my/asia/our-team/) (C) 2019 Published by Readers Insight Publisher, lat 306 Savoy Residencia, Block 3 F11/1,44000 Islamabad. Pakistan, info@readersinsight.net This is an open access article under the CC BY-NC-ND license (http://creativecommons.org/licenses/by-nc-nd/4.0/). 


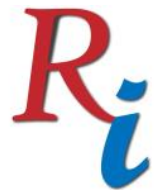

\section{Asia Proceedings of Social Sciences \\ (APSS) \\ www.readersinsight.net/APSS}

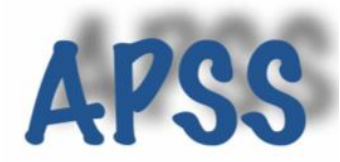

\section{Rese a r ch H i g h I igh t s}

It is undeniably true that the digital disruption situation is unavoidable and real. The use of financial technology (fintech) is a prerequisite nowadays and was no longer an alternative back in those days. Consumers can have all the banking services available at their fingers through smart devices and this creates a good user experience. However, it shall be noted that although fintech has provided the consumers with much convenience, it should not distract the main purpose of banking industries for being the 'safekeeper' of consumers' money. The challenge faced by Takaful operation due to digital disruption is either to adapt to it or suffer a slow death. One of the initiatives taken by Takaful Malaysia is to collaborate with software company Fusionex to transform its core software and to promote social media marketing. The response was very welcome and about 40 million insurance policies was sold on its digital platform since its first product launched online within a period of three months. ${ }^{1}$ Takaful Malaysia on the the hand is putting in effort seeking to reach more people especially the senior citizens with no or minimal knowledge Internet knowledge and also rural customers who lack of internet access.

\section{Research Objectives}

This paper objectively studies the challenges faced by Takaful Operators as a result of application of financial technology (fintech) in Islamic Fintech globally with focus in operation of Takaful in Malaysia through analytical research methods by utilizing existing facts and findings on Fintech to make proposals for possible issues. Both applied and fundamental research methods are employed to explore on the challenges to regulate Islamic Fintech in Takaful Operation in this jurisdiction.

\section{Methodology}

While the scarcity of studies on this area is apparent, the authors have identified the undebatable need to regulate the development of the Fintech Industry and its effects while analyzing the drawbacks and positive effects of Fintech towards parties involved in IBF industry. The research methodology in this research will be a legal research which is predominantly library based limited to the view of Islamic Fintech in Malaysia.

\section{Results}

The impact of fintech in Takaful Operation is not all negative as fintech is not about to kill traditional players. There are still sizeable customer segments that are only comfortable dealing with agents in buying insurance. However, over time, traditional players may face significant reduction in their customer base as those who have grown up using the Internet and mobile devices form the majority of the population. Traditional players need to consider work together with fintech players and leverage on their technology partners. At the same time, they can focus on specialisations in the business segments that cannot be easily replicated by non-traditional players. On the overall Islamic finance scene, fintech in the Islamic finance space positively contributes to the development of the Islamic finance products and services offering including Takaful. Fintech will result in improved professionalism of intermediaries that will not only focus on sales, but also ensure adequate advice.

\footnotetext{
${ }^{1}$ What's Next 2017: Adapt now or die, "What's Next 2017: Adapt Now or Die" (November 13, 2017) <https://www.digitalnewsasia.com/digital-economy/what-next-2017-adapt-now-or-die> accessed May 5, 2018

Copyright $\odot 2019$ Authors. This is an open access article distributed under the Creative Commons Attribution License, which permits unrestricted use, distribution, and reproduction in any medium, provided the original work is properly cited.
} 


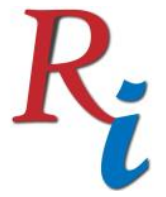

\author{
Asia Proceedings of Social Sciences \\ (APSS) \\ www.readersinsight.net/APSS
}

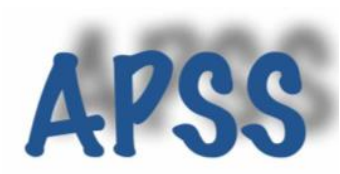

\title{
Findings
}

In Malaysia, consumers are beginning slowly to do more banking online as well as research and purchase financial products like credit cards and personal loans. Recently, more insurance products have been placed online on aggregators and price comparison websites as well as directly by insurers. Bank Negara Malaysia has announced the implementation of fintech regulatory sandbox framework to support innovation that improves the quality, efficiency, and accessibility of financial services in the country. There are many banks including Islamic banks started to join the fintech players.

\section{Acknowledgement}

The authors would like to thank to the Ministry of Higher Education (MOHE) for sponsoring this work under project (FRGS/1/2018/SSI10/MMU) and Faculty of Law, Multimedia University, Melaka (MMU) for the moral support throughout the research.

\section{References}

"Disrupting Islamic Finance" (The Edge MarketsNovember 14, 2017) <http://www.theedgemarkets.com/article/cover-story-disrupting-islamic-finance>

"Fintech, Digital Disruption Debate Should Not Distract Banking Industry" Borneo Post Online (March 31 , 2018) <http://www.theborneopost.com/2018/03/31/fintech-digital-disruption-debateshould-not-distract-banking-industry/> accessed May 5, 2018

"Impact of Fintech to Islamic Finance" (The Malaysian Reserve April 3, 2017) <https://themalaysianreserve.com/2017/04/03/impact-of-fintech-to-islamic-finance/>

'Halal Fintech Offers A Great Opportunity For Islamic Finance' (The Malaysian Reserve, 2018) $<$ https://themalaysianreserve.com/2018/02/12/halal-fintech-offers-great-opportunityislamic-finance/> accessed 22 May 2018

Impact of Fintech to Islamic finance. Available at: https://www.islamicfinance.com/2016/04/impactfintech-islamic-finance/ [Accessed 19 May 2018].

Khairani Afifi Noordin, "Cover Story: Disrupting Islamic Finance” [2017] The Egde Malaysia Weekly 